Loewenberg, Gerhard, Samuel C. Patterson, and Malcolm E. Jewell. 1985. Handbook of Legislative Research. Cambridge, MA: Harvard University Press.

Mayhew, David R. 1974. The Electoral Connection. New Haven: Yale University Press.

McCoy, Drew R. 1980. The Elusive Republic: Political Economy in Jeffersonian America. Chapel Hill: University of North Carolina Press, Institute of Early American History and Culture.

Peabody, Robert L. 1969. "Research on Congress: A Coming of Age." In Ralph K. Huitt and Robert L. Peabody, eds., Congress: Two Decades of Analysis. New York: Harper \& Row.

Polsby, Nelson W. 1968. "The Institutionalization of the U.S. House of Representatives." American Political Science Review 68: 144-168.

Price, H. Douglas. 1975. "Congress and the Evolution of Legislative 'Professionalism.' "' In Norman J. Ornstein, ed., Congress in Change: Evolution and Reform. New York: Praeger.

Schattschneider, E. E. 1975. The Semisovereign People. Hinsdale, IL: The Drysdale Press.
Shepsle, Kenneth A. 1979. "Institutional Arrangements and Equilibrium in Multidimensional Voting Models." American Journal of Political Science 23: 27-48.

Shepsle, Kenneth A., and Barry R. Weingast. 1987. "The Institutional Foundations of Committee Power." American Political Science Review 81: 85-104.

Silbey, Joel H. 1985. The Partisan Imperative. New York: Oxford University Press.

Sinclair, Barbara. 1989. The Transformation of the U.S. Senate. Baltimore: The Johns Hopkins University Press.

Skladony, Thomas W. 1985. "The House Goes to Work: Select and Standing Committees in the U.S. House of Representatives," Congress and the Presidency 12: $165-188$.

Stewart, Charles H. 1989. Budget Reform Politics: The Design of the Appropriations Process in the House of Representatives, 1865-1921. New York: Cambridge University Press.

Swift, Elaine K. 1987-1988. "The Electoral Connection Meets the Past: Lessons from Congressional History, 1789-1899."

Political Science Quarterly 102: 625-645. 1989. "Reconstitutive Change in the U.S. Congress: The Early Senate,
1789-1841." Legislative Studies Quarterly 14: $175-204$.

Thompson, Margaret Susan. 1985. The "Spider Web." Congress and Lobbying in the Age of Grant. Ithaca: Cornell University Press.

Watts, Steven. 1987. The Republic Reborn: War and the Making of Liberal America, 1790-1820. Baltimore: Johns Hopkins University Press.

Wood, Gordon S. 1969. The Creation of the American Republic, 1776-1787. New York: Norton.

\section{About the Authors}

Elaine $K$. Swift is an assistant professor of political science at the University of North Carolina-Chapel Hill. She is currently working on a book on the reconstitution of the U.S. Senate, 1789 to 1841 .

David W. Brady is a professor of political science at Stanford University. His most recent book, Critical Elections and Congressional Policy Making, won the APSA's Richard F. Fenno, Jr. Prize in 1989.

\title{
The Political Scientist as Comparative Election Observer
}

\author{
William Crotty, Northwestern University
}

When you have witnessed elections in Chicago, you may think you have seen everything. Not so. The range of elections in Third World countries-from the politics, the efforts to mobilize voters, the attempts to institute democratic forms and educate people as to their relevance, and the stakes involved-is staggering. The wealth of opportunities for observing election performance in a variety of world settings approaches experimental laboratory conditions.

On a different and more important level, the significance of elections for the people involved-the sharing of power, the institution of a sense of accountability for actions in office, the representation of all interests in the society, the recognition of individual worth and an acceptance of the sanctity of human life, the institutionalization of the rule of law and due process guarantees, and, more often than not, the promise of a better life-is difficult to overestimate. Expectations are high. The consequences of both the outcomes and the manner in which the elections are conducted are of fundamental importance to the society's future.

Elections can never carry all the burdens laid upon them. They can make a beginning in some, or all, of the objectives attributed to them and, at times, the results border on the spectacular (Chile); at other times, and more rarely, the election experience is one more chapter in the brutalization and suppression of a people (Haiti, 1987).

Presumably democratic elections can also be used to justify a course of action or a particular foreign policy emphasis (El Salvador, 1984), "demonstration elections" as Edward S. Herman and Frank Brodhead (1984) have labeled them; or they can lead to tenuous but often significant efforts to institute democratic procedures and a commitment to democratic values (Honduras, 1980; Nicaragua, 1984, 1990; Argentina, 1983). The results can be incomplete and the forms and obligations left after the elections can be rudimentary and fragile, subject to violation and open to abuse. In most of the elections I observed, I suspect this is the case. However, from a long-term perspective, a beginning has been made.

For most nations that hold such elections, a formal and public commitment to entertain democratic standards of worth and democratic criteria of performance has been initiated. Whatever the motivations, an implicit willingness or need (given grudgingly on occasion) has been indicated to join the community of nations and to apply universal standards of democratic fairness and civility to the manner in which government operates.

\section{The Importance of Independent Observers}

Why go? In my experience, reporters in interpreting events in foreign countries are heavily dependent on 
information and access supplied by the U.S. Embassy. More often than not, the media is sympathetic to the American government's position. Reporters ordinarily have little knowledge of a country or its politics and little concern with placing the election in question in an indigenous context historically relevant to the developments taking place. The story is how it impacts on U.S. interests. In addition, human rights concerns, the focal point for many of the delegations I went on, are submerged in an emphasis on Cold War politics and the "realities" of a struggle over an international order. Any type of relevant media attention thus can be difficult. This, in turn of course, limits access to the American public.

While there are no guarantees that an observer team's evaluations would differ from those of the State Department's or the administration's, the likelihood is that on occasion they will. This has proved to be the case. The lack of access to the major media - and more recently, the limits put on the media coverage itself (the Grenada and Panama invasions; the Saudi-Iraq build-up) raise basic questions about the information available to Americans to make informed judgments about their own best interests. The problems here, of course, go well beyond the interpretation of election outcomes.

Congress is also a target. It was believed that many in the Congress were sympathetic to human rights concerns but had little independently verifiable information and that many others were at least open to views, if grounded in experience, other than those of the administration. Given the stakes, emphasized by the developments in Nicaragua and El Salvador in particular over the decade of the eighties, it was believed that an effort to open alternative communication channels to, in this case, Central America was worth the effort.

These were the concerns of the early delegations I went on. They were not necessarily the same concerns of later groups or those with a different policy agenda. What should be familiar to most, however, are the nature of the problems encountered and the uncertainty of the enterprises. The experiences were new in the early 1980 s, but by the Nicaraguan election of 1990 , the movement culminated in an acceptance of outside verification as an integral part of the election experience.

It should be noted, however, that the use of election observers even in the early 1980s was not altogether new. The American government has employed election observers in Vietnam during the 1960s and 1970s to certify elections there as being fair and democratic. ${ }^{1}$ In addition, Lord Chitnis, a Liberal member of Britain's House of Lords, had observed the Zimbabwe-Rhodesian elections of 1979 and 1980 . His reports on Zimbabwe had enormous effect; they eventually came to represent, rather than the British government's or others' assessments, the standard as to whether the elections were to be perceived as fair or representative. (Lord Chitnis was also involved in evaluating the Salvadoran and Nicaraguan elections of 1984) (Chitnis 1984). While relatively unknown to the broader public, there was then a role model emerging as to the potential integrity and impact of the observer process. Whether it could be repeated in Latin America was another matter.

\section{The Role of the Observer}

Anyone who has had training as a survey research interviewer or in the "value-free" traditions of behavioralism should have some familiarity with the expectations of election observing. The election observer was expected to assess as independently, thoroughly and accurately as he or she could:

the nature of the election campaign, from the relevance of issues raised to the selection of candidates, and the mobilization of voters;

the accessibility and uses made of the media and the openness of debate;

the domestic and foreign conflict the campaign took place within and how these impacted on the process;

the adequacy of the procedures for identifying and certifying the eligible members of the electorate; the quality of information possessed by the citizenry, their understanding of the process and their willingness and ability to make independent judgments and to cast a free and representative ballot; and

the operations and integrity of the formal election machinery, from the manner in which ballots were printed and the composition and role of local election officials to the final vote count.

It is this last aspect of the process, the procedures for casting a vote and, of even greater attention, the perception as to whether the vote count was fair, that most groupsboth private and official as well as the media-fix on as the indicator of an acceptable election. It is what people understand and what they presume others will accept. In addition, efforts to comprehend and encapsulate the process became relatively manageable by focusing on the election machinery itself.

Undoubtedly, the vote certification process is important. However, it is but one part of a larger picture and taken out of context is meaningless. Many factors can invalidate a representative vote. For example, soldiers quizzing prospective voters about their choice; rules excluding sizeable proportions of the electorate; campaigns conducted in a climate of fear and suppression; political parties unrepresented outside the larger cities; prohibitions placed on organization by worker or professional groups; restrictions on the accessibility of media outlets or the substance of appeals that can be made by opposition candidates; limits on the funds or time periods or locations or types of rallies to be made available for campaign purposes, all contribute to less than perfect elections. Yet such restrictions are relatively subtle. They usually receive only passing attention from the American media in assessing the adequacy of the process. They normally become the focus of direct concern only to the extent the American government or its embassy raises questions or links the events to its interests.

Given the problems, is election observing an impossible assignment? 
Clearly not. The election process is amenable to adequate coverage by even relatively small private groups. I believe this has been demonstrated and is now accepted as fact. Surprisingly perhaps, even the most incompatible of ideological brethren, assuming they make a conscientious effort, can usually agree on what happened in an election and how the process functioned. What they disagree on is the relative importance of what they observed and the implications of the outcome. This is where personal values, individual judgments, and political commitments come into play.

Perhaps the biggest single point of controversy is the role of the observer. Different conceptions account for contrasting emphasis in reports and for a good deal of dissension in individual delegations. Some believe, as I have argued, that the observer is meant to make, to the best of his or her ability, an objective, professional judgment, independent of personal preferences or other concerns and free of pressure from governments or other groups. Many share this view; many others do not. Some believe the observer is a partisan, unambiguously promoting one point of view; or a "witness" to an event who can recount the experience in other contexts and provide some type of personal testament or assurance or validity to the process; or a publicist or ideologue who recognizes the broader issues and commits to a higher ideal ("freedom," a presumed threat to the security of the United States, a struggle against subversion, "anti-communism," "a free enterprise system'). The promotion of such ideas becomes more important than any independent assessment, the latter seen as but one step in a broader war. Others believe the observer should be an activist, someone who pitches in and helps out, casting aside any pretense of neutrality.

The arguments over the observer's role, even after initial agreements have been reached on these points before leaving the United States, can create intense personal and group conflicts. Alternative conceptions of role and commitments largely accounts for the often confusing and contradictory conclusions reached by observer teams. ${ }^{2}$ In such a situation, an academician can appear removed, insensitive and naive, not understanding the real implications of the process. The only counter is that the integrity of the final report depends on the objectivity of the observers.

\section{Evaluating the Elections: The Worst, The Best and Those In-Between}

In all, I have had the opportunity to observe seven elections in six countries under a variety of conditions. The contests were of differing levels of importance to the United States and the American government played a number of roles. These ranged from patron to supportive (but not controlling) to opposing, the latter at times with great determination. All of the elections I observed had one important thing in common: each was believed to be a major step in instituting democratic rule, a (potentially) critical turning point in the development of, and commitment to, democratic forms. This did not always turn out to be the case. But it was the belief held prior to each election, and it is the dimension that runs through and distinguishes them.

A brief sketch of my visits to each of these countries follows. Necessarily it is personal and impressionistic and reflects my own observations and values.

Honduras, 1981, 1983. The 1981 election in Honduras, intended to institute civilian authority after a period of military rule, a contest and concern that took on added significance for the United States given the increased fighting and American involvement in neighboring $\mathrm{El}$ Salvador and Nicaragua. On an observation mission trip in 1983, the immensity of the changes had become apparent. Civilians rules in name, but the military-greatly expanded, enriched, modernized and, if anything, more powerful-held the real power. The "era of national security" had been instituted and suspected "leftists" were imprisoned if lucky, or "disappeared" at will. An active opposition, democratic institutions, an open press and a strong and independent court system and national congress had progressed little. The American ambassador served as a type of proconsul with a say, on behalf of the United States, in everything of importance that happened in the country. Human rights abuses, once relatively restricted, grew in number and intensity; evidence of which we saw firsthand. National Guard units from the U.S. were arriving to build transportation centers and roads from the coast ports to the Nicaraguan border; airports had been expanded for military use; refugees from, in particular, El Salvador, were camped on the western borders in both 1981 and 1983 under United Nations supervision and subject to repeated attacks from the Salvadoran military; and the Contra encampments and the problems caused by their presence in an officially neutral country were just beginning to receive extensive attention. The impressions I took with me ranged from the frustration and anger voiced repeatedly by the democratic opposition to an understanding of how quickly a situation can change and the overwhelming impact the United States can have when it decides something is in its national interest. Alternatively, and still evident on the second trip, Americans gave little attention and few resources to the civil society, and they evidenced no particular concern with the nation's poverty and other social problems.

Argentina, 1983. Nobody was quite sure the military, clearly unpopular as it was and discredited by the Malvenas/Falklands venture, would either permit an open campaign or would surrender power once an election was held. The days leading up to the election were tense but the vote itself well received. This election was one of the successes. As the vote came in, literally millions of people marched through the streets of Buenos Aires celebrating. The willingness of the Peronist candidate to certify the election as fair and to recognize the Alfonsin victory were critical. The disastrous state of the economy and the unresolved status of responsibility for the human rights abuses conducted under the military insured that the Radical Democrats and their successors would have difficulty meeting the nation's needs and 
that the democratic experiment might well continue to prove uncertain.

El Salvador, 1984. El Salvador is a police state. The election was conducted during a period of civil war and as a show piece for American foreign policy with the idea of legitimating the U.S. military investment and providing some visible indications of change toward a more democratic system through the election of a civilian government, preferably that of the Christian Democrats and Jose Duarte. Enormous sums of money were invested in the latest computerized vote reporting and polling techniques. Efforts were made to facilitate the work of the reporters and observer teams who operated through the officially recognized Salvadoran agencies (photo opportunities, press conferences, personal interviews, helicopters to outlying polling places, facilities for televising news). For those who struck out on their own, it could be dangerous (as four Dutch journalists were to find out).

It would be difficult to call the election democratic. A significant proportion of opinion within the country was not represented in the vote; the political parties did not organize broadly or attempt to represent all levels of social opinion; campaigning was restricted; the U.S. government took a direct interest in the outcome and the procedures employed, supplying funds, expert advice, and technical assistance to the government and the election administration and heavily promoting its interpretation of the process; intimidation, violence, and human rights abuses never really ceased; there were no impartial media; voting at the local level took place under military control and, for example, in transparent ballot boxes; and the military retained effective power.

Little has changed since then. Yet it is instructive to go back and read the newspapers or to view in television archives the highly favorable interpretations of the election as given in a Cold War context and the reputable media and public figures (in addition, of course, to the Reagan Administration) that strongly endorsed the process.

Nicaragua, 1984, 1990. These were easily the most controversial and most significant elections, from a U.S. policy standpoint, of the decade. They were also among the fairest in terms of procedures and the most extensively covered. Perhaps the best thing to do in this context is to indicate the evaluations offered by the delegations sponsored by the Latin American Studies Association (LASA) to observe the elections. Writing in 1984, the LASA delegation reported that

“ . . the Nicaraguan electoral law of 1984 provided a broad array of protections to assure fair access, procedural honesty, and an accurate vote count. The actual voting process was meticulously designed to minimize the potential for abuses. The vote was truly a secret ballot, and was generally perceived as such by voters. We observed no evidence of irregularities in the voting or vote-counting process"' (p. 1).

\section{Or again in 1990:}
"The principal technical characteristics of the elections, including successful negotiation by all parties over electoral rules, highly competent and even- handed administration of the election by the Consejo Supremo Electoral (CSE), a low degree of systematic coercion by any of the contending parties, a basic level of human rights protection, the broad ability of the parties to participate in the process, albeit with unequal resources, has led the Latin American Studies Associa- tion (LASA) Commission to a judg- ment that the process, although occa- sionally problematic, was fundamen- tally democratic"' (p. 1).

It is fair to say that the views expressed in the 1984 LASA report were not the ones that prevailed in the United States. The LASA reports can be used to illustrate another point: the immediate policy consequences of such elections; the heated nature of the rhetoric involved, an intensity unfamiliar to those who specialize in American politics; and the enormous stakes involved in the interpretation of what has happened.

For example, the following can be found in the 1984 LASA report:

\footnotetext{
"Clearly the Nicaraguan electoral process in 1984 was manipulated, as the U.S. Government so often
}

charged. However, the manipulation was not the work of the Sandinistaswho had every interest in making these elections as demonstrably fair, pluralistic, and competitive as possible-but of the Reagan Administration, whose interest apparently was in making the elections seem as unfair, ideologically one-sided, and uncompetitive as possible.

... The most plausible explanation for such conduct, in our view, is the deep, ideologically grounded hostility of the Reagan Administration toward the Sandinista government, whose elimination has been the primary objective of U.S. policy toward Nicaragua at least since December, 1981, when President Reagan authorized a CIA-run 'secret war' against the FSLN government' (p. 31).

\section{Or in the 1990 LASA report:}

\begin{abstract}
"The 1990 Nicaraguan elections represented a 'free and fair' electoral process within a climate of United Statesgenerated military and economic pressure. . . . A review of the dreary, often illegal, behavior of the United States in marshaling military, economic and diplomatic power against a small, weak country suggests that U.S. foreign policy has altered its modalities but not its fundamental intentions toward Latin America. The great difficulty it had in pursuing this policy of undermining a sovereign nation shows that such behavior is increasingly subject to the criticism of North American citizens as well as other countries"' (pp. 45-46).
\end{abstract}

The bluntness of wording and tone of concern for human costs implicit in such depictions indicate the importance attached to processes seemingly open to independent and unemotional judgment. There are few neutrals in such debates.

Haiti, 1987. The worst of the experiences would have to be Haiti's. The military's commitment to giving up power and to instituting democratic processes to replace the Duvalier legacy had always been suspect. As the days of the campaign progressed, the last restraints broke: dead bodies were found in the streets or in front of campaign headquarters; two candidates were killed, one on the steps of police headquarters; reporters and observer teams were forcibly prohibited from traveling to the north of 
the country or much outside of Portau-Prince immediately prior to the vote; vigilante groups formed to protect neighborhoods, resulting in constant street violence; and many candidates went into hiding. On election day, the violence erupted fully, with scores of voters (the totals range from a low of 34 to over 200 or 400 ; no one is sure of the number) shot, macheted, and brutalized by Ton Ton Macoutes-a kind of secret police or intimidation squad under the Duvaliers-and soldiers. The elections were suspended. Many of the observer teams and media representatives were taken out of Haiti on special planes contracted for by the State Department (Crotty 1988).

Eventually the military was to hold its own election and choose, and then depose, a civilian candidate as president.

The country remains in a state of uncertainty, poverty, and repression. The problems continue unaddressed: the lack of an economic base; the exhaustion of natural resources; over-population; the absence of social services and the presence of archaic educational and health delivery systems; rampant corruption and exploitation of office; drug-dealing; a complete insensitivity to human rights and individual life; and an untrained and uncontrollable military. The promise of new elections are constantly being held forth to a people with little else to look forward to.

Chile, 1988. Chile represents one of the true successes, an election in which a dictator managed to get himself voted out of office. General Augusto Pinochet held a plebiscite to lend legitimacy to his remaining in the presidency for an additional eight years. He lost. Despite the difficulty of mobilizing clandestinely and of conducting a campaign in constant fear that it could lead to imprisonment or worse and despite the difficulty of uniting an opposition that ranged from right-wing former civilian supporters of the government through Christian Democrats, including former associates of Salvador Allende, killed in the 1973 coup that installed Pinochet, to Socialists and the outlawed Communist Party on the left, the movement succeeded. Whether the government would accept the results of the plebescite was in question until the early morning hours. It did and although Pinochet remained as head of the military and a member of the upper house of parliament, the process of reconciliation had begun. A year later, Patricio Alywin, the Christian Democratic candidate, was elected president by the coalition and negotiations extended to further permit democratic practices and to reach some type of accounting for the "disappeared"' (International Human Rights Law Group 1989).

Each experience is different and each election significant. The variety of contexts that an observer can be placed in is great and the weight given the interpretation of results can magnify the pressure. The intensity of the experience can be unsettling and the immediate relevance of the conclusions reached intimidating. The efforts are academic, political, and personal all at once, with little from past experience or practice to guide the observer.

\section{The Future of Election Observing}

From its humble beginnings, observing elections has grown into a major political industry. There were over 2,500 accredited observers at the 1990 Nicaraguan election. Governments and parliaments send their own observer teams. The United Nations and the Organization of American States mounted massive efforts to monitor the process in Nicaragua. Both began early. Each oversaw the formation of the electoral council that conducted the election; the registration process; the different phases of the campaign; the vote; and the change in governments. It was the largest operation of its kind and one that may well provide a model for future elections.

In addition, the Carter Center staffed an office and a delegation led by former President Jimmy Carter, the Council of Freely-Elected Heads of Government, monitored the process. Carter, in particular, became actively involved in resolving disputes, contributing to a climate hospitable to peaceful decision- making, and in facilitating the acceptance of the results and the transitions of governments (Council of Freely-Elected Heads of Government 1990).

There are more government-established agencies to provide technical election assistance with boards of directors made up of public figures from both of the major political parties. The International Foundation for Electoral Systems, founded in 1987 by the Agency for International Development, can provide technical and administrative assistance and training to countries holding elections.

The National Endowment for Democracy, a bipartisan, government-funded agency, is actively involved in promoting democracy worldwide, including supplying observer teams, technical assistance, expert advice, and funding to groups it believes shares its values as it did in Nicaragua. The political parties now have their international wings, a decidedly new development for parties in the United States. The Democratic Party, through its National Democratic Institute for International Affairs (NDI), has been particularly aggressive in observing elections in other countries (e.g., Bulgaria, Czechoslovakia, Pakistan, the Dominican Republic, Haiti, Panama, Poland, and Romania among other places). The NDI in addition reports "conducting a series of democratic development agencies" in approximately thirty countries (NDI Reports 1990).

Small (and not so small), independent policy groups (Freedom House, Casa Nicaragua, and the Puebla Institute, as examples) still have a role in election observing, but even this has begun to change. Hemisphere Initiatives, a new group formed primarily to monitor the Nicaragua election and promote economic development in Central America, conducted two nationwide surveys in Nicaragua using a well-known Washington polling firm, and it produced a series of studies prior to the election that ". . . were the most widely circulated and well-received reports produced by any of the international nongovernmental organizations monitoring the Nicaraguan elections" (Hemisphere Initiatives 1990). 
The International Human Rights Law Group, which began its election observing modestly and somewhat tenuously in the early 1980s, now has a guide for election observers and has expanded its operations to include such countries as Argentina, Nicaragua, Uruguay, Grenada, El Salvador, Zimbabwe, Guatemala, the Philippines, and Korea.

All of this may be to the good. Large groups, conscientiously directed, can cover more ground, process more information and have a greater impact on the proceedings than smaller groups. But there are dangers implicit in the developments also. There is a question as to how much intervention outside groups should impose on a process. How much is beneficial and to what extent should nations and peoples be left to find their own way? When does one cross the line from "observer" to "participant?', Who decides when "participation" is warranted or how much is healthy and how much is enough? Such questions deserved to be asked. Good intentions could conceivably lead to unfortunate interventions.

There is a fear also that larger, politically sensitive groups may not have the freedom of action of smaller groups, that consensus-building among 30 or 40 to 100 or more politically prominent figures can lead to a dilution of the group's observations and potentially to a desire to please a host government or, more likely, an effort to trim evaluations to affect political debate in the United States. The cost of operations of larger delegations can greatly exceed the resources of private agencies. Election observing should not become one more extension of Washington, D.C., a large-scale, pro forma exercise that rewards electoral friends and punishes electoral enemies. There is a role for smaller groups, although being heard may be at least as difficult now as it ever was.

No one any longer doubts the value of election observing or its potential impact. The effort now should be to ensure that the process retains its integrity and its independence and that it allows for a diversity of group opinions and views.

Finally, there is the problem of the elections themselves. They are taken as a symbolic, as well as a real, commitment to democratic decisionmaking. In effect, they represent a universal shorthand that people everywhere can use as a quick gauge of democratic performance.

Democracy is complex and needs nurturing. It is a process over time that can be vulnerable to disruption or redirection. Flections are but one step in a long and continuing chain. The process begins well before any elections are held and continues in its often uncertain way long after public attention has been directed elsewhere.

One recent example will help to make the point. In November of 1988, Pakistan held an election. A civilian government was voted into office and Benazir Bhutto was elected Prime Minister. The vote was witnessed by election observer delegations, including one from the National Democratic Institute (International Delegation Report 1989). In August of 1990, Bhutto and her government were dismissed, allegedly at the behest of the military.

There were problems, and the Bhutto administration had proven to be a disappointment. The fear was that new elections might not take place and if they did the government chosen would not be democratic.

The scenario could be present in any Third World country attempting to institute democratic forms. The failure was laid, in the words of a New York Times' correspondent, to " . . . a feudal social structure, corrupt bureaucracies and law-enforcement agencies, an interfering military, a poor and illiterate electorate and a political elite bereft of vision and addicted to power." Is it much wonder that the "civilian administration expected to put Pakistan back on the road to democracy and growth"' collapsed? (Crossette 1990).

There is a "crash" that follows elections. The institutions needed to maintain a demcratic system and keep it afloat are not in place; the countries normally have a weak or absent history of democratic traditions; democratic values are not widely held by either the leadership or the masses; the economies are ravaged; and the military remains the one social institution with real power.

Elections are an important, even critical, link in democratic govern- ance. They should be widely monitored and broadly assessed from a number of vantage points. However, important or symbolic, they remain but one step in a long evolution, a process that does not end when the votes are counted.

\section{Notes}

* This article is adapted from a paper prepared for the 86th meeting of the American Political Science Association, San Francisco, CA, August 30-September 3, 1990.

1. See the report contained in Appendix 2 of Demonstration Elections, 1984, pp. 222-37. Compare this with the report in Appendix 3, pp. 234-43.

2. See the Freedom House reports on Zimbabwe, Rhodesia, and El Salvador contained in Herman and Brodbeck, Appendix 1, pp. 206-22, as an example. Compare these with "Free and Fair? The 1979 Rhodesian Election," 1979, and Claire Palley, The Rhodesian Elections, 1979.

\section{References}

Chitnis, Lord. 1984. The Election in Nicaragua: 4 November 1984. York, England: Beverly House, 1984.

Council of Freely-Elected Heads of Government. 1990. Observing Nicaragua's Elections, 1989-1990. Atlanta, GA: The Carter Center of Emory University.

Crossette, Barbara. 1990. "Pakistanis Wary on New Elections." New York Times, August 12, p. 3.

Crotty, William. 1987. The Election in Haiti. Washington, DC: Council on Hemispheric Affairs.

. 1988. "Elections and Chaos in Haiti." Washington, DC: A paper delivered at the Fourteenth World Congress, International Political Science Association, September 1, 1988.

1977. Political Reform and the

American Experiment. New York: Thomas Y. Crowell.

1980. "The Franchise: Registration

Changes and Voter Representation." In W. Crotty, ed., Paths to Political Reform. Lexington, MA: Lexington Books/D.C. Heath, 1980. Pp. 67-113.

"Free and Fair? The 1979 Rhodesian Election." 1979. A Report by Observers on Behalf of the British Parliamentary Human Rights Group. Sanctions. Pp. 280-347.

Hemisphere Initiatives. 1990. Report on Hemisphere Initiatives' First Initiative: Monitoring the Nicaraguan Elections. Boston, MA: Hemisphere Initiatives.

Herman, Edward S., and Frank Brodbeck. 1984. Demonstration Elections. Boston: South Fnd Press.

International Delegation Report. 1989. Pakistan Elections: Foundation for Democracy. Washington, DC: National Democratic Institute for International Affairs. 
International Human Rights Law Group. 1989. Chile: The Plebiscite and Beyond. Washington, DC: International Human Rights Law Group. February.

Latin American Studies Association. 1990. Electoral Democracy Under International Pressure. Pittsburgh, PA: LASA Secretariat. . 1984. The Electoral Process in Nicaragua: Domestic and International Influences. Austin, TX: LASA Secretariat. NDI Reports. 1990. Washington, D.C. National Democratic Institute for International Affairs, Summer.

Palley, Claire. 1979. The Rhodesian Elections. London: Catholic Institute for International Relations.

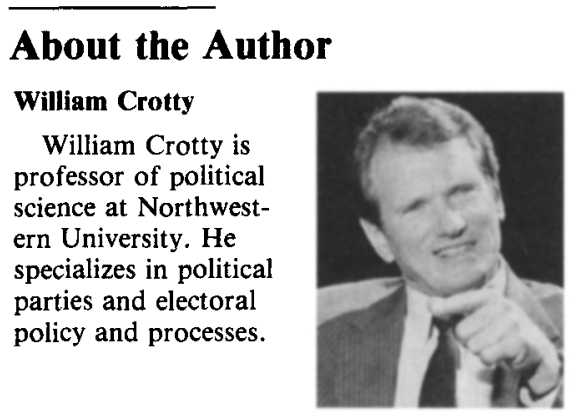

\title{
Why a Political Film Society?
}

\author{
Michael Haas, University of Hawaii at Manoa
}

Just as all life itself has political meaning, producers of commercial films operate within a political context. In most cases films have an implicit message, but in some cases the aim of a film is to make an important and explicit political statement.

My interest in political films dates from 1950, when the era of McCarthyism was reaching its peak. Courageous members of the film industry were being blacklisted, some for their political courage, others for frivolous reasons. The film community emerged from the shock of the blacklisting era rather quietly. Politically oriented films were rare in the 1950 s, compared to the consciousness raising of the 1940s, and the 1960s were tame compared to the 1970 s and 1980s.

The full story of the rise of political films has yet to be told, but it would certainly include The Birth of the Nation earlier in the century. One of the more contemporary landmarks was Warren Beatty's effort to portray the way the American Communist
Party was suppressed after World War I. After major film studios refused to produce his idea for such a film, he formed his own corporation to produce Reds, which combined a distinct political message with some "Don Juan" touches to make a film in the 1970s that would be at least marginally marketable.

The next major political film came in 1984. The Killing Fields emerged as possibly the most influential political film of all time. The horrors of the Pol Pot era in Cambodia had been reported in print, but the depth of the inhumanity was largely unappreciated until the film provided a portrayal unparalleled in the history of film. Most filmviewers are unaware that the producers cut a portion of the film that showed the joyous manner in which Cambodians greeted Vietnamese soldiers as liberators of their country from Pol Pot. Even so, later changes in U.S. policy toward Cambodia, which then covertly supported the Khmer Rouge, may be in some measure due to the success of The Killing Fields in raising the consciousness of millions of viewers.

Since political films entail considerable risk, they are still rare and usually uncelebrated. Accordingly, I decided to found the Political Film Society in 1986 as the first society in the world to recognize outstanding films with important political messages. The aim is to encourage more political films by rewarding those who know that political consciousness can be raised through film in a very special way.

Originally, the Political Film Society was formed as a project of the former Hawaii Political Studies Association (HPSA). At the first HPSA meeting a group of persons got together to review a proposed set of by-laws modelled closely on the constitution of the Academy of Motion Picture Arts and Sciences, which makes the annual academy awards. Since our aim was to reward content, not technical accomplishments, we established four major 